\title{
«В начале было Слово...», а в конце будет число? Православие и антицифровой протест в России: с 1990-х до коронавируса ${ }^{1}$
}

\author{
Б.К. КНОРРЕ*, А.А. МУРАШОВА**
}

\begin{abstract}
*Борис Кириллович Кнорре - кандидат философских наук, доцент, старший научный сотрудник, Национальный исследовательский университет «Высшая школа экономики». Адрес: 101000, Москва, ул. Мясницкая, д. 20. E-mail: bknorre@hse.ru

**Анна Алексеевна Мурашова - стажер-исследователь, Национальный исследовательский университет «Высшая школа экономики». Адрес: 101000, Москва, ул. Мясницкая, д. 20. E-mail: murashova.hse@gmail.com
\end{abstract}

Цитирование: Кнорре Б.К., Мурашова А.А. (2021) «В начале было Слово...», а в конце будет число? Православие и антицифровой протест в России: с 1990-х до коронавируса // Мир России. Т. 30. № 2. С. 146-166. DOI: $10.17323 / 1811-038 \mathrm{X}-2021-30-2-146-166$

Статья посвящена анализу развития антищифровых протестов среди православных фундаменталистских и консервативных групп в России. Цель работь - выяснить, каковы основные тенденции этих протестов, на какие идеи они опираются. Рассматривается период с конца 1990-х годов до 2020 года включительно, начиная с первых выступлений против введения шттри-кодов и ИНН и заканчивая реакцией православных движений на цифровизационные инициативы государственной власти во время пандемии COVID-19. Установлено, что, несмотря на то что антицифровой протест преимущественно связан с фундаменталистско-консервативныли православныли течениями, их представители в последние годы чаще обращаются к распространенному на Западе дискурсу защитьл прав и свобод. Делается вывод о том, что в современном российском православии можно выделить два кластера: первый, направленный на визуально-физическое посредничество для взаимодействия с трансиендентным (именно он обеспечивает сегодня антицифровые протесты), и второй кластер, ориентированный на интеллектуальное и этическое понимание религии, представители которого относятся гораздо спокойнее к внедрению ичифровых технологий.

1 Исследование осуществлено в рамках Программы фундаментальных исследований НИУ ВШЭ. 
Ключевые слова: православие, цифровизация, Русская Православная Церковь, консерватизм, фундаментализм, защита персональных данных, COVID-19

\section{Краткая история антицифровых протестов: конец 1990-х - начало 2000-х}

Впервые протесты против цифровизации в российской православной среде начались в конце 1990-х гг. в связи с введением штрих-кодов и идентификационных номеров налогоплательщиков (ИНН), которые в ряде православных сообществ, в частности в греческой и грузинской церковной фундаменталистской среде, были восприняты в мистико-апокалиптическом ключе: три пары разделительных линий, находящихся в штрих-кодах, интерпретировались как число «666» («число антихриста») (Откровение Иоанна Богослова 13:16-18) [Верховский 2003, с. 73-77]. Эту аргументацию поддержали и православные верующие постсоветского периода, многие из которых оказались новообращенными в православие, что способствовало радикализации позиции неприятия штрих-кодов и ИНН. Их возражения сводились к мистико-апокалиптической трактовке штрих-кодов и ИНН, т. к. они усмотрели наличие апокалиптического «числа зверя» - 666 «в штрих-кодовой системе EAN-13», отмечая, что «нельзя предположить, что данная символика в европейской системе могла возникнуть случайно» [Боголюбов 2000]. Параллельно высказывались опасения относительно недопустимого вмешательства в личную жизнь, но в качестве мистического и собственно религиозного обоснования непреложно указывалось на то, что наличие «числа зверя» 666 в ИНН и штрихкодах доказано [Лампси 2001]. Наиболее непримиримой позиции в данной ситуации придерживались монархически ориентированные церковные фундаменталисты, заявившие о своей готовности бороться против использования штрих-кодов и ИНН верующими. Помимо фундаменталистов, к антицифровому протесту присоединились православные консерваторы, отличающиеся от фундаменталистов отсутствием четко выраженных политических претензий повлиять на общество 2 .

В 2000 г. в Санкт-Петербурге сформировалось движение «За право жить без ИНН, личных кодов и микрочипов» под руководством В.П. Филимонова, православного писателя, инженера в области кибернетики. Совместно с фундаменталистскими организациями в Санкт-Петербурге и Москве руководство этого движения организовывало молитвенные стояния, демонстрации против принятия ИНН и штрих-кодов, провело конференции «Россия перед вызовом глобализма», «Православие и Россия в свете Апокалипсиса» [Шнирельман 2017, с. 499]. Аналогичные мероприятия состоялись в 2003-2004 гг. в Самаре, Ростове-на-Дону, Нижнем Новгороде, Иваново, Липецке [Открытое обращение 2004].

\footnotetext{
2 Различие между протестами православных фундаменталистов и консерваторов состояло в том, что если первые ставили своей задачей воздействие на общество, то вторые готовы были смириться с наличием цифровых форм контроля в силу лояльности к государственной власти. Их основное опасение - страх перед изменением существующих религиозных традиций из-за технических новшеств. При этом и фундаменталисты, и консерваторы выражали резкое неприятие цифровизации, хотя и в разных формах. В данной статье мы используем методологию и подходы к определению фундаментализма [Riesebrodt 1998; Lawrence 1989] и ориентируемся на данные ими определения подобных групп.
} 
Идейными вдохновителями выступлений против ИНН стали авторитетные духовники из среды монашества, движение поддержали знаменитые монастыри: Троице-Сергиева лавра, Валаамский монастырь, Оптина пустынь и другие [Верховский 2003, с. 83] - и даже некоторые архиереи: архиепископ Владивостокский и Приморский Вениамин (Пушкарь), епископ Чукотский и Анадырский Диомид (Дзюбан), епископ Уфимский и Стерлитамакский Никон (Васюков), архиепископ Вятский и Слободской Хрисанф (Чепиль), митрополит Ювеналий (Тарасов) [Верховский 2003, с. 78-83].

Поскольку ИНН, против которого выступали протестующие, по их мнению, должен был заменить в документах христианское имя человека, то его, как указывалось выше, посчитали «печатью антихриста». Наиболее радикальные приверженцы этой позиции среди священнослужителей даже начали отлучать от причастия прихожан, получивших ИНН [Верховский 2003, с. 84]. Священный Синод Русской Православной Церкви высказался против практики отлучения от причастия, но поддержал озабоченность православных консервативных движений относительно принудительности присвоения ИНН, заняв умеренную позицию касательно богословского толкования этого явления. Позиция священноначалия Русской Православной Церкви (РПЦ) относительно ИНН выразилась в том, что верующим гражданам должна быть предоставлена вариативность в выборе средств учета [Заявление Священного Синода 2000], а также четкое описание процедуры сбора и использования его данных [Итоговый документ VII Пленума Синодальной Богословской комиссии 2001]. Впоследствии (в 2008 и 2011 гг.) разъяснения на эту тему давались в определениях Архиерейских Соборов, в которых говорилось о недопустимости тех методов учета граждан, которые вторгаются в их частную жизнь, и о необходимости обеспечения добровольности использования гражданами электронных средств идентификации [Определение Освященного Архиерейского Собора 2008; Определение Освященного Архиерейского Собора 2011]. Наконец, в 2013 г. Архиерейским Собором был принят документ под названием «Позиция Церкви в связи с развитием технологий учета и обработки персональных данных», цель которого состояла в обращении внимания властей и общества на наличие большого количества православных верующих, обоснованно предпочитающих старые традиционные средства учета, и на факты дискриминации таких граждан и нарушения их конституционных прав в условиях политики навязывания цифровых средств. В документе утверждалось, что в результате безальтернативного внедрения новых идентификационных систем «формируется целый слой людей, выброшенных из всех сфер общественной и государственной жизни» [Позиция Церкви 2013]. Поддержав опасения верующих, РПЦ все же осудила выводы некоторых православных проповедников, отождествивших эти средства с «печатью антихриста» [Заявление Священного Синода 2000].

Следует отметить, что после первых заявлений священноначалия РПЦ изменилась сама риторика православных активистов против ИНН. Во-первых, номер стал расцениваться не как «печать антихриста», а как шаг к принятию такой печати. Во-вторых, аргумент о том, что ИНН заменяет христианское имя, начал использоваться более широко, поскольку он никак не был осужден в официальных документах РПЦ. В-третьих, что наиболее примечательно, ИНН и впоследствии другие электронные средства учета стали восприниматься преимущественно как 
важнейший элемент глобализации - соответственно, протесты против ИНН явились частью антиглобализационного протеста [Верховский 2003, с. 80-82]. С тех пор антицифровизационная составляющая в значительной степени является частью протестов против глобализма.

В следующих главах будут приведены основные аргументы и тенденции дальнейшего развития антицифрового протеста в российском православии. В ходе исследования мы использовали материалы конференции [Принудительная оцифровка личности 2019] и сайта, созданного Комитетом по защите персональных данных [Онлайн-митинг 2020], являющиеся непосредственными источниками информации о позиции цифроскептиков. Также статьи цифроскептиков опубликованы на ресурсах «Русская народная линия» и «РИА “Катюша”» - консервативно-фундаменталистских изданиях, позиционирующих себя в качестве апологетов православных традиционных ценностей и преимущественно предоставляющих площадку священникам и церковным деятелям. Мы использовали также видеоматериалы православного телеканала «Спас» в выпусках передачи «До самой сути» [До самой сути: Электронный концлагерь 2019; До самой сути: Биометрическое рабство 2018], отдельные публикации православной консервативной радиостанции «Радонеж», консервативно-монархического телеканала «Царьград-ТВ» и православной фундаменталистской газеты «Русь Державная». Все это составляет первичную информационную базу обоснования антицифрового протеста. Для сопоставления этой аргументации с официальной позицией Церкви были исследованы документы РПЦ. Отметим также, что само обозначение «цифроскептик» применительно к православным верующим, протестующим против цифровизации, недостаточно передает остроту их позиции, но мы будем пользоваться этим обозначением как синонимом слова «антицифровик» в силу того, что сами протестующие иногда готовы идентифицировать себя с цифроскептиками.

\section{Особенности религиозного восприятия: культура слова vS культура цифры}

За мистико-апокалиптическим восприятием цифровых технологий в церковной среде стоят глубокие культурно-эстетические и мировоззренческие установки. В присвоении и использовании разного рода цифровых идентификаторов православные активисты усматривают опасность вытеснения человеческого имени, которое (если оно присутствует в святцах), по православному вероучению, связывает человека с его святым покровителем, через него осуществляются молитвы о человеке, оно выступает как символ, через который поддерживается связь с богом. Активисты антицифрового протеста считают, что идентификация человека через его имя важна не только во время молитв, но и в повседневной жизни, и какая-либо другая идентификация в повседневности является угрозой для христианского самоощущения человека. Так, В.П. Филимонов возражает против использования СНИЛС (страхового номера индивидуального лицевого счета), усматривая в нем замену обычного человеческого имени на «имя цифровое», которое будет служить как «сквозной идентификатор личности», причем не только при жизни человека, но и после его смерти [Филимонов (1) 2020]. 
Цифровые идентификационные системы активисты также воспринимают как опасность замены образа божьего цифровым портретом: так, В.П. Филимонов расценивает биометрию как недопустимое «вторжение в храм Духа Святаго Божиего», «надругательство над образом Божиим в человеке», потому что, претендуя на конфиденциальные данные о человеке, биометрия претендует на всеведение, по праву доступное лишь богу [Филимонов (1) 2020]. На самом деле не только в биометрии, но и в системах цифрового учета, и в целом в стремлении просчитать природу человека, спрогнозировать его желания, предпочтения и поведение в целом православные противники цифровизации видят попытку узурпировать ту силу, которая свойственна только богу. В подтверждение такой позиции фундаменталисты предпочитают апеллировать к библейскому примеру из Второй книги Царств (24:11-19), где обличается решение царя Давида провести перепись населения, и за этим решением следует суровое наказание. В этой связи предполагается, что стремление государства овладеть исчерпывающими сведениями о своих гражданах - признак приближения царства антихриста, который вознамерится установить единое планетарное государство, осуществляющее тотальный контроль над всеми его гражданами ${ }^{3}$. Протестуя против универсальной электронной карты (УЭК), противники цифровых технологий сетуют на то, что УЭК по своему функционалу приближается к чему-то наподобие цифрового портрета человека, в чем видят угрозу подмены образа божьего на мнимый виртуальный образ.

В отмеченных случаях неприятия цифровых идентификаций на самом деле присутствует важный для православного сознания мировоззренческий подход нежелание признавать идею о возможности аналитического просчета человеческой души. В этом случае явно просматривается протест против прогрессистской идеи цифрового оценивания эмоций и желаний человека научными средствами, то есть того, что укладывается в понятие «цифровой портрет». Для объяснения этой мировоззренческой установки воспользуемся аргументацией, которую продемонстрировал богослов Н.К. Гаврюшин, показывая несовместимость идей регуляции природы Н.Ф. Федорова с православным богословием и мироощущением. Он упрекал Н.Ф. Федорова за то, что последний, желая найти способы воскрешения человека, верил в возможность полного аналитического описания человека, в т. ч. человеческой души, показывая тем самым «непонимание самодовлеющей ценности образа, его рациональной неисчерпаемости» и, напротив, давая «интерпретацию его как знака-указания на то или иное логизируемое знание, умозрительную схему» [Гаврюшин 1983, с. 251].

Н.К. Гаврюшин утверждал, что, согласно православному миропониманию и православной антропологии, человеческая душа и человеческая личность не могут быть аналитически разделимы. Говоря об изъяне идей Н.Ф. Федорова, он писал: «Эта аналитическая ослепленность, полагающая не только личность, но и необходимо и любую целостность составимой из частей, не видит вокруг себя ничего живого, все живое ей непонятно и должно быть подчинено рациональному механизму» [Гаврюшин 1983, с. 245]. Разложимость личности на части, по его мнению, упрощает ее понимание, лишает таинственных глубин, резкого качественного отличия от всякой материи, потому что «единственной подлинной

3 Интервью Б.К. Кнорре с протоиереем Игорем Тарасовым (Коломна, 20 октября 2017 г.). 
реальностью» личности в таком случае становятся «атомы и молекулы, на которые личность якобы распадается и из которых она мнится быть составимой» [Гаврюшин 1983, с. 245]. Православные активисты антицифрового протеста, конечно, не формулируют своего неприятия методов цифровой идентификации человека на столь высоком богословском уровне, однако многие их высказывания позволяют сделать вывод, что для них цифровизация неприемлема во многом из-за неготовности к представлению о человеке как о чем-то просчитываемом, а значит, состоящем из отдельных частей и элементов. В этом случае культура визуализации вступает в конфликт с культурой дигитализации: фактически в антицифровом протесте православных верующих демонстрируется борьба «слова» и «цифры» - телесности и визуализации, присущих православию, со знаково-числовой рациональной культурой. Христианское имя, как некий целостный, эстетически окрашенный символ, в этом контексте представляется той ценностью, которая противостоит идентификационным номерам и номерам документов.

Монахиня Мария (Скобцова) описывала пять типов религиозного благочестия, отмечая при этом, что в православии наиболее распространенным является эстетический, а не рациональный, т. е. характерно преобладание эстетизма в религиозности православных верующих, связанного с особым значением вещественности, телесности и визуализации, а также с культом старины [Скобцова 2012], когда особым почитанием пользуются именно старинные иконы или древние витиеватые распевы. Согласно исследованию М. Винна, для верующих важно то, с чем они соприкасаются, поскольку история этого соприкосновения формирует священность предметов и мест [Wynn 2009]. В этой связи совсем не случайным становится стремление к восстановлению полностью разрушенных храмов и монастырей, причем именно на тех же местах, где они когда-то существовали, а также почитание мощей святых и принадлежавших им предметов. Все это свидетельствует о сильном значении вещественности, поэтому угроза вытеснения на периферию в условиях цифровизации религиозных практик, связанных с тем или иным вещественным выражением, добавляет «эффект обнуления» религии [Смирнов 2019]. Также не удивительно, что идея присвоения номеров гражданам наряду с фамилией, именем, отчеством в рамках внедрения тех или иных цифровых систем учета противоречит превалирующему среди православных типу благочестия, которое наделяет слово и имя особым значением.

В конце концов, в процессе цифровизации цифроскептики видят глобальную отрицательную тенденцию и ввиду того, что смещение идентификации человека в сторону числовых кодов, отказ от культуры слова в пользу культуры цифры рассматривается как отход от фундаментальных принципов установленного Богом бытия, выраженного первой фразой Евангелия от Иоанна «В начале было Слово, и Слово было у Бога, и Слово было Бог...» (Ин. 1, 1), где в качестве Слова (Логоса) понимается сам Христос, источник жизни и всякого бытия. Поэтому ответ на вопрос, насколько правомерна постепенная замена слов и имен на цифровые обозначения, для многих консерваторов однозначен: такая замена - это шаг от Христа. В обобщающем смысле данный нерв опасений выражен книгой одного из наиболее мистически и конспирологически ориентированных идеологов антицифрового протеста экономиста В.Ю. Катасонова «В начале было Слово, а в конце будет цифра» [Катасонов 2019], в названии которой звучит отсылка к вышеупомянутому месту из Евангелия от Иоанна. 


\section{Политические экспликации неприятия цифры: теории заговора и охранительство}

Религиозно-мистическое восприятие цифровизации вынуждает православных фундаменталистов и консерваторов видеть в ней не объективное следствие научно-технического прогресса, а объяснять ее воздействием внешних сил. Для многих ревнителей веры цифровизация - это плод заговора узкой группы лиц, которые входят в правительства и олигархические группы западных стран, поставляющих в Россию цифровое оборудование, с одной стороны, а также банкиров, желающих заполучить контроль над платежами граждан, и лоббистов цифровизационных законопроектов, с другой [Филимонов (1) 2020]. Основной целью сторонников цифровизации они видят установление мирового правительства для воцарения антихриста. Активисты придают эсхатологический характер цифровизации и верят в планы масонского «мирового закулисья», т. е. мыслят в рамках конспирологической культуры [Barkun 2003].

В сложившейся ситуации Россия представляет собой оплот православия, находящегося в кольце врагов, которые стремятся (в т. ч. с помощью новых технологий) его уничтожить. Соответственно аргументация против цифровизации часто идет в одной связке с охранительной риторикой, в рамках которой опасность электронных средств учета данных рассматривается как угроза суверенитету России в силу того, что они считаются инструментом глобализации. Единые системы учета персональных данных (ЕГИССО, Госуслуг и Мосрег), по мнению активистов, несут гигантские риски, потому что утечкой данных из этих систем могут воспользоваться западные страны [До самой сути: Электронный концлагерь 2019].

Дискурс безопасности - одна из наиболее заметных проекций антицифровой настройки православных фундаменталистов на политическую тональность. Проблемы цифровизации в этой среде обсуждают именно на политическом языке, что демонстрирует их ярко выраженное военно-оборонительное сознание, о чем свидетельствуют названия мероприятий: «Вопросы духовной безопасности в информационном обществе» ${ }^{4}$, «Тотальная цифровизация общества - угроза государственности и национальной идентичности», «Проект "Цифровая экономика РФ" несет угрозу безопасности страны и не должен стать идеологией новой, расчлененной России» [Проект «Цифровая экономика РФ» 2017] и т. п.

Цифроскептиков волнует перспектива децентрализации государства, «отмена управляющей и контролирующей роли государства, расплавление механизмов государственности, разрушение государственного управления, $<\ldots>$ потеря государством возможности осуществлять свои функции и защищать свой суверенитет» [Проект «Цифровая экономика РФ» 2017]. Эти опасения в более мягкой форме разделяет Патриарх Московский и всея Руси Кирилл: «Мы не должны покупаться ни на какие игрушки, в том числе цифровые, чтобы в какой-то момент не оказаться рабами этой технологической цивилизации, центром управления которой будет не наша суверенная страна» [Предстоятель Русской Церкви 2019].

\footnotetext{
4 Постоянно действующий круглый стол, организованный Украинской православной церковью Московского Патриархата по благословению митрополита Киевского и всея Украины Онуфрия.
} 
Такая акцентированность на вопросах национальной безопасности объяснима в контексте феномена, подмеченного норвежским исследователем Ж. Остбо, «секьюритизации духовно-нравственных ценностей» [Østbø 2016]. В его исследовании продемонстрировано, что духовно-нравственные ценности в России стали определяться как вопрос национальной безопасности на самых высоких уровнях государственной политики. Узкая концепция «духовной безопасности» возникла в середине 1990-х и была первоначально направлена против привносимых с Запада новых религиозных движений, но позже ее расширили до признания духовно-нравственных ценностей вопросом национальной безопасности. Поскольку РПЦ активно добивалась такого признания, ее представители хорошо усвоили секьюритационную риторику, а православные фундаменталисты со свойственным им изоляционизмом и манихейским взглядом на мир не только охотно ее подхватили, но и усилили, развивая на ее основе разного рода объяснения мировых процессов.

\title{
Тотальный контроль над личностью, угрозы правам и свободам
}

Несмотря на ярко выраженные охранительские тенденции, в антицифровом движении присутствует и противоположная линия аргументации, подчеркивающая не опасность потери контроля государством граждан и угроз безопасности, a, наоборот, тревогу по поводу ограничения свободы личности (в т. ч. со стороны государства).

Доводы конституционно-правового характера, направленные на защиту личных прав и свобод цифроскептиков, можно обнаружить в самом начале их протестов, но к концу 2010-х гг. их число значительно увеличилось. Главное опасение цифроскептиков состоит в том, что новые технологии позволят осуществлять тотальный контроль над личностью, и, как следствие, права и свободы граждан окажутся под угрозой.

\begin{abstract}
«Отслеживая повседневную жизнь “проштрихованного” гражданина <..., можно будет составить подробный психологический и даже психофизиологический портрет владельца УЭК. Общенаучные данные в области физиологии, психологии давно используются для разработки способов давления на человека в особых ситуащиях» [Тотальный контроль 2013].
\end{abstract}

Критика звучит по отношению к универсальным электронным картам (УЭК) не только как к средствам идентификации личности, но и как к платежным средствам, ведущим к изъятию наличных денег из оборота. Протоиерей Максим Колесник ${ }^{5}$ считает, что проект «Цифровая экономика» прямо нацелен на тотальный контроль над гражданами.

5 Настоятель храма Новомучеников и исповедников Домодедовских в г. Домодедово Московской области. 
«Нам лукаво говорят о ичфровой экономике. На самом деле это лукавый термин. Экономика - это прежде всего жизнедеятельность человека, а человеку нужны реальные товары и услуги, а не цифровые. Термин “иифровая экономика" - на самом деле это электронный контроль над жизнедеятельностью человека» [Онлайн-митинг 2020].

Для обоснования своей позиции активисты - Николай Мишустин ${ }^{6}$, Ольга Леткова ${ }^{7}$, Анна Швабауэр ${ }^{8}$ и другие - подробно анализируют нормативные правовые акты, законопроекты и подзаконные акты, публикуют в социальных сетях образцы жалоб и заявлений. Например, рассмотрев закон о биометрической идентификации, антицифровики нашли в нем ряд угроз: отсутствие перечня собираемой информации о гражданах, передача биометрических данных в правоохранительные органы без согласия владельца, расширение списка оснований для отказа в обслуживании гражданина банком - что подготавливает почву для дискриминации несогласных на обработку биометрических данных [Парламентарии не поняли смысл закона 2018]. Иными словами, православные активисты подчеркивают опасность ограничения прав и свобод, дискриминации тех, кто не будет согласен на использование тех или иных методов цифровой идентификации.

Дискриминационные элементы, по мнению антицифровиков, прописаны и в Федеральном законе «О государственной социальной помощи», где сказано, что без согласия на обработку персональных данных эта помощь не оказывается. Консерваторы свидетельствуют о случаях, когда органы государственной власти в нарушение Федерального закона «Об организации предоставления государственных и муниципальных услуг» отказывали гражданам в использовании альтернативных средств (бумажных носителей) [Принудительная оцифровка личности 2019].

"Если все население в принудительном порядке и "бесплатно" переводят на "иифру", не оставляя при этом альтернатив (или что еще хуже - искусственно делая их невыгодными), то это реальный повод задуматься о том, как эта новая “ұифровая" реальность будет использоваться государством» [Цифровая продажа 2017].

Озвучиваются опасения, что технологии как инструмент оказываются в руках ограниченного числа лиц, чьи моральные качества не известны и кто может распорядиться им в своих корыстных целях [До самой сути: Биометрическое рабство 2018]. Операторы персональных данных - либо государство, либо частные компании - могут продавать данные граждан.

\footnotetext{
6 Основатель движения «Родительский отпор», общественный деятель.

7 Общественный уполномоченный по защите семьи в Санкт-Петербурге и Ленинградской области.

8 Юрист, эксперт при Общественном уполномоченном по защите семьи в Санкт-Петербурге и Ленинградской области, кандидат юридических наук.
} 
«Вы понимаете, во что они хотят нас превратить? В рынок! Чтобы человек был товаром!» [Онлайн-митинг 2020].

Православных цифроскептиков, как правило, одинаково волнует опасность контроля над личностью как со стороны государства, так и со стороны крупных корпораций, который может качественно усилиться из-за введения цифровых технологий. Это звучит достаточно обоснованно, поскольку, как отмечает Н. Ричардс, «это взаимосвязанные части одной и той же проблемы, они не дискретны» [Richards 2013, p. 1935]. Государство, как было сказано выше, осуществляет контроль, принимая цифровизационные законопроекты и не оставляя гражданам альтернатив в виде традиционных средств учета. Корпорации, в свою очередь, получают доступ к данным граждан через делегирование государством им своих функций, о чем пишет В.П. Филимонов: «Полномочия государственных органов передаются МФЦ, а от МФЦ - банкам» либо через предоставление корпорациями своих услуг, например, крупным IT-компаниям, которые стремятся захватить мир [Филимонов 2019].

\section{В условиях пандемии}

С наступлением пандемии коронавируса в марте 2020 г. в России цифровизационные законопроекты получают форсированное развитие в силу перехода множества сфер на дистанционный формат коммуникации. В епархии РПЦ были направлены распоряжения губернаторов не допускать массового скопления людей в храмах и перевести их участие в дистантный формат с помощью видеотрансляций. Это было особенно болезненно воспринято в связи с интенсивным литургическим временем для православных - окончанием Великого поста в апреле и приближающейся Пасхой, традиционно отмечаемой в заполненных храмах, при максимальном числе причащающихся из одной Чаши.

Вопреки обычно демонстрируемой лояльности действиям гражданских властей, не только рядовые верующие, но и отдельные церковные лидеры отказывались подчиняться ограничительным мерам: например, митрополит Саратовский Лонгин заявил, что готов обеспечить возможность массового богослужения на Пасху с участием всех желающих [Корчагин 2020]. С публичными протестами выступили православные активисты в Екатеринбурге, Москве, Санкт-Петербурге и других городах. Требования перевода богослужений на дистанционный формат они комментировали как завуалированную форму гонений на верующих, подчеркивая, что распространение ограничений на посещение храмов при работающих торговых центрах представляется по меньшей мере непоследовательным шагом со стороны властей ${ }^{9}$ Об угрозе ограничения прав и свобод открыто начинали

\footnotetext{
9 Этот аргумент авторам статьи не раз приводили и православные активисты, добивавшиеся открытия храмов в апреле 2020 г. См., в частности, комментарии к посту известной православной активистки Оксаны Ивановой «Я поняла, почему на Церковь наезжают, а на ТЦ нет» (запись в личном блоге О. Ивановой от 10 апреля 2020 // https://www.facebook.com/ioksana).
} 
говорить те, кто раньше выступал исключительно за усиление централизации государства и силовых методов управления, например, схиигумен Сергий (Романов) ${ }^{10}$. Он был убежден, что цифровизация - это обман, имеющий своей целью лишить граждан права свободно перемещаться, посещать храмы и выбирать, как им жить [Российский священник проклял сторонников закрытия 2020].

Один из лидеров антицифрового протеста в фундаменталистских кругах протоиерей Максим Колесник сравнивал цифровой пропускной режим с «фашистской оккупацией», отмечая, что нынешние власти делают граждан партизанами в своем же городе. Он апеллировал к известному лозунгу Б. Франклина «Кто готов пожертвовать свободой ради безопасности, не достоин ни свободы, ни безопасности» и озвучил явную антисекьюритационную позицию, доказывая губительность охранительства.

«Под рассказы о вамей безопасности города поделят на сектора с разным доступом, в Интернет будете входить по паспорту, жить по разрешению, передвигаться только по пропуску, у каждого будут свой номер и бирка, как в лагере» [Колесник 2020].

Православные фундаменталисты выражали недовольство тем, что Государственная Дума принимала цифровизационные законопроекты в предельно короткие сроки, не давая общественности полноценно ознакомиться с ними. Предотвращение распространения коронавируса оценивалось как мнимая цель этих законопроектов, маскирующая желание государства ограничить свободу граждан [Онлайн-митинг 2020]. Таким образом, фокус внимания активистов антицифрового протеста сместился с угроз национальной безопасности на угрозы тотального контроля над населением и ограничения свобод передвижения с помощью QR-кодов ${ }^{11}$.

Можно констатировать наличие метаморфозы, заключавшейся в том, что в православных фундаменталистско-консервативных кругах начали гораздо громче, чем раньше, говорить на не свойственном им правозащитном языке, выступая против цифровых ограничительных мер, в то время как ориентированные на западный мир и либеральные ценности верующие, наоборот, оставались более спокойны к введению ограничений и воспринимали как должное необходимость освоения цифровых механизмов для онлайн-участия в богослужении ${ }^{12}$.

\footnotetext{
10 В мае 2020 г. схиигумен Сергий был запрещен в священнослужении, а позже лишен сана за эксцентричные проповеди, в которых он публично отрицал существование коронавируса, проклинал церковную и светскую власть за закрытие храмов на период самоизоляции. Его мнение для нас важно, т. к. в течение примерно 15 лет до этого он пользовался большим авторитетом у церковных фундаменталистов, имел влияние на часть силовой российской элиты.

11 Выступающие против цифровизации православные издания давали своим материалам соответствующие заголовки: «От коронавируса - к единому цифровому концлагерю», «Кто готовит рабство в России», «Тайна частной жизни отменяется новым законом!», «Коронавирус пройдет рано или поздно, а тотальная слежка останется» [Соченко 2020; Романов 2020; Четверикова 2020, Филимонов (2) 2020].
}

12 Например, Преображенское братство создало ҮouTube-канал с прямыми трансляциями богослужений (см.: https://www.youtube.com/c/RusOrthodoxPrayer). 
Наконец, выждав паузу в оценке происходящего в период пандемии, в более мягкой форме, но поддерживающей опасения православных активистов по поводу контроля над населением, 25 августа 2020 г. высказался в своем послании Синод РПЦ:

«B значительной степени оправданной видится обеспокоенность многих христиан, как и людей различных иных убеждений, возможностью дальнейтего применения методов, которыми во время эпидемии обеспечивалось необходимое снижение интенсивности личных контактов между людьми. Использование иифрровых идентификаторов, автоматизированное принятие решений, могущих повлечь поражение людей и изельх сообществ в правах, широкий сбор личных данных, в том числе сведений о здоровье, а также обработка этих данных - все это требует контроля со стороны общества, в том числе со стороны Церкви как общественного института» [Послание Священного Синода 2020].

Еще один интересный феномен заключается в том, что антицифровики, высказываясь против СНИЛС и УЭК, апеллируют к зарубежному законодательству, отмечая, что «в Англии, Франции, Германии отсутствует “единый реестр населения" с номерным идентификатором гражданина, поскольку эти механизмы расцениваются как грубое нарушение конституционных прав граждан» [Требуем отклонить законопроект 2020]. Возражая против введения QR-кодов, они указывали на предостережение Совета Европы против ограничения прав и свобод под предлогом коронавируса и на нормативы Европейской Конвенции о защите прав человека.

Заметим, что некоторые идеи, на которые опираются российские антицифровики, были заимствованы у американских протестантских фундаменталистов, хотя первые и не хотят это признавать [Панченко 2015, с. 125-127]. Начиная с 1970-х гг. американцы высказывали опасения относительно формирования Европейского союза и глобализации, которая должна, по их мнению, подготовить почву для пришествия антихриста [Boyer 1992, p. 277], орудием которого называли новые технические средства, позволяющие обеспечить контроль над действиями граждан [Lyon 1994].

\section{В рамках формата публичной религии: попытки демаргинализации}

Как отмечалось исследователями, современные религиозные движения характеризуются все большим проникновением в публичную сферу [Casanova 1992, Heclo, Mc Clay 2003], и российское православие не является исключением: его переходом от «частной религии» к «публичной» можно объяснить развитие православных антицифровых движений и их риторики. Проанализируем действия антицифровиков сквозь призму этой концепции, в которой можно выделить несколько компонентов [Zabaev, Mikhailova, Oreshina 2018]. 
1. Начнем с присутствия религиозной группы в масс-медиа. Весьма показательно высказывание Андрея Кормухина ${ }^{13}$, жалующегося на то, что крупные СМИ стремятся маргинализировать цифроскептиков, отказывая им в предоставлении слова: «Нас представили такими мракобесами, сектантами, маргиналами» [Принудительная оцифровка личности 2019]. Антицифровым движениям приходится в основном довольствоваться своими каналами распространения информации, создавая собственные сайты, страницы в соцсетях, каналы на YouTube. Обсуждать проблемы цифровизации удается лишь в церковных СМИ, например, на телеканале «Спас» [До самой сути: Электронный концлагерь 2019; До самой сути: Биометрическое рабство 2018], канале «Царьград» и радио «Радонеж» [Новикова-Строганова 2014; Иваткина 2019]. Несмотря на неприязнь к технологиям, цифроскептики демонстрируют поразительную активность в сети, что типично для фундаменталистов, чьим отличительным признаком является использование средств модернизации для популяризации архаических идей [Митрофанова 2004, c. 27-30]. В мае 2020 г., когда пандемия не оставила иного выбора, активисты даже провели мероприятие в новом формате - онлайн-митинг «Человек не номер!» [Онлайн-митинг 2020].

2. В рамках аспекта «публичной религии» имеют место быть попытки влияния религиозной группы на государство. Православные антицифровики не просто выступают против отдельных явлений технологического развития общества они рефлексируют над политическими процессами, анализируют законопроекты. В своих заявлениях активисты обращаются к президенту, правительству, Государственной Думе, отдельным депутатам и чиновникам с критическими заявлениями, порой небезрезультатно: так, критика проекта «Цифровая экономика» привела к тому, что его рассмотрение стало повесткой заседания Совета Безопасности РФ в июне 2017 г. [Проект «Цифровая экономика РФ» 2017]. В мае 2020 г. обращения цифроскептиков в Государственную Думу вынудили депутатов отложить обсуждение законопроектов о регистре населения и биометрической идентификации [Народные протесты 2020].

Антицифровые движения предпринимают попытки повлиять на ситуацию не только на федеральном уровне, но и на региональном. В своих группах в социальных сетях они публикуют образцы жалоб и заявлений в органы исполнительной власти ${ }^{14}$. На этом уровне антицифровикам чаще удается защитить свои интересы и отстоять право на пользование традиционными средствами учета при получении госуслуг, при устройстве детей в детские сады и школы.

3. Религиозные группы затрагивают вопросы, касающиеся всего общества, поднимают тему обработки персональных данных. В их риторике присутствует эсхатологический элемент: активисты рассуждают о цифровизации как об угрозе всему человечеству. Кроме того, рассматривая это явление сквозь призму антиглобализма, православные движения видят в нем угрозу безопасности и интересам нации.

4. Коммуникация между антицифровиками как религиозной группой и обществом могла бы играть немаловажную роль, однако прямой обмен аргументами как таковой отсутствует. Вместо него имеет место критика цифровых проектов со стороны православных активистов, которая чаще всего не получает ответа.

\footnotetext{
13 Глава парамилитаристского православного движения «Сорок Сороков», приближенного к Патриарху Кириллу.

14 Например, «Родительский отпор» (https://vk.com/club88227371) и Общественный уполномоченный по защите семьи в Санкт-Петербурге (https://vk.com/detipeterburg).
} 
5. Религиозная группа в рамках феномена «публичной религии» выступает как моральный актор. И антицифровики для того, чтобы помочь желающим отстоять свои моральные права на пользование традиционными средствами учета, концентрируются на информационной и юридической помощи всем желающим.

Таким образом, православные фундаменталисты и консерваторы предпринимают все возможные попытки демаргинализироваться в глазах общества и государства. Об этом же может свидетельствовать и их стремление приглашать на свои мероприятия известных артистов и заручаться поддержкой людей из академической среды: так, в вышеупомянутом онлайн-митинге против цифровизации выступили актриса Мария Шукшина, телеведущая Анна Шафран, а в числе лидеров антицифрового протеста выступают профессора МГИМО Ольга Четверикова и Валентин Катасонов.

\section{Заключение}

Дискуссии вокруг внедрения цифровых технологий, усилившиеся в связи с пандемией коронавируса, показали, что в российском православии можно выделить два кластера групп верующих, один из которых ориентирован на «материальную религию», подчеркивающую важность визуального, физического контакта, необходимость наглядного физического посредничества для взаимодействия с трансцендентным, а второй - на рациональное богословское и этическое понимание религии. В каком-то смысле второй кластер коррелирует с феноменом «виртуальной религии», вернее, позволяет легче к ней адаптироваться, принять ее специфику. Первый кластер - в большей степени удел фундаменталистов и консерваторов (хотя эта корреляция не исчерпывающая), второй - удел диаконически ориентированных православных верующих, а также тех, кто настроен относительно позитивно в отношении перспектив развития общества («прогрессистов») и, наконец, тех, кого можно отнести к условно либеральным течениям православия.

Нельзя не признать, что неприятие или настороженное отношение к цифровым технологиям остается доминирующей чертой российского православия. При этом за протестами против цифровизации стоят две противоречащие друг другу тенденции: с одной стороны, цифроскептики возражают против цифровых технологий с позиций охранительства и культурного суверенитета, с другой, выступают с позиций борьбы за приватность личного пространства и опасений потери привычных форм коммуникации перед лицом непредсказуемости контролирующего эффекта цифровых технологий. В итоге последняя тенденция вынуждает прибегнуть к правозащитному дискурсу, использовать понятийный аппарат западного правосознания, несмотря на свойственное им противопоставление архаики и примордиальности либерально-глобалистскому типу культуры. В ходе развития собственного правозащитного языка они стараются расширять свои дискуссионные площадки, привлекать известные медиаресурсы и медийные персоны для популяризации своих идей, делают свои аргументы более понятными для широкой публики, иными словами, происходит демаргинализация антицифрового протеста и усвоение им атрибутов публичной религии. 


\section{Литература}

Боголюбов И.Д. (2000) Не спешите каяться за всех // Pravoslavie.ru // https://narod.pravoslavie.ru/shengen/kuraev_inn.htm

Верховский А.М. (2003) Политическое православие: Русские православные националисты и фундаменталисты, 1995-2001 гг. М.: Центр «Сова».

Гаврюшин Н.К. [А.М.] (1983) Воскрешение чаемое или восхищаемое? // Богословские труды. № 24. С. 242-259.

До самой сути: Биометрическое рабство (2018) // Телеканал «СПАС». 5 декабря 2018 // https://www.youtube.com/watch?v=05mmr8 rwg4

До самой сути: Электронный концлагерь (2019) // Телеканал «СПАС». 25 июля 2019 // https://www.youtube.com/watch?v=I8HJN16iGCw

Заявление Священного Синода (2000) // Patriarchia.ru. 7 марта 2000 // http://www.patriarchia.ru/db/text/4898206.html

Иваткина М. (2019) «Запаситесь валерьянкой»: эксперты раскритиковали законопроект «О цифровом профиле» // Царьград-ТВ. 14 ноября 2019 // https://tsargrad.tv/articles/ zapasites-valerjankoj-jeksperty-raskritikovali-zakonoproekt-o-cifrovom-profile_225857

Итоговый документ VII Пленума Синодальной Богословской комиссии РПЦ, посвященной вопросу об ИНН (2001) // Азбука веры. 4 марта 2001 // https://azbyka.ru/otechnik/dokumenty/itogovyj-dokument-7-plenuma-sinodalnojbogoslovskoj-komissii-russkoj-pravoslavnoj-tserkvi-posvjashhennoj-voprosu-ob-inn/

Катасонов В.Ю. (2019) В начале было Слово, а в конце будет цифра. Статьи и очерки. М.: Кислород.

Колесник М. (2020) Запись // ВКонтакте. 21 апреля 2020// https://vk.com/wall211228203 4100 Корчагин Л. (2020) Запись // ВКонтакте. 18 апреля $2020 / / \mathrm{https}: / / \mathrm{vk.com} /$ wall434012891_2381 Лампси А. (2001) ИНН в православных СМИ // НГ-религии. 28 февраля $2 \overline{001} / /$ https://www.ng.ru/ng religii/2001-02-28/5 analysis.html

Медведева И., Шишова Т. (2020) Попытка нравственного переворота // РИА «Катюша». 24 июня 2020 // http://katyusha.org/view?id=14604

Митрофанова А. (2004) Политизация «православного мира». М.: Наука.

Народные протесты заставили Думу отложить рассмотрение законопроекта о регистре населения на неделю и снять с повестки биометрию (2020) // Комитет по защите персональных данных. 14 мая 2020 // http://cifroskeptik.net/2020/05/14/narodnye-protesty-zastavili-dumu-otl/

Новикова-Строганова А. (2019) Электронно-торговая кабала // Радонеж. 18 декабря 2014 // https://radonezh.ru/analytics/elektronno-torgovaya-kabala-122420.html

Онлайн-митинг «Человек не номер!» (2020) // «Иван-Чай». 6 мая 2020 // https://www.youtube.com/watch?v=1g4E3Xltdgc

Определение Освященного Архиерейского Собора Русской Православной Церкви 24-29 июня 2008 года «О вопросах внутренней жизни и внешней деятельности Русской Православной Церкви» (2008) // Patriarchia.ru. 27 июня 2008 // http://www.patriarchia.ru/db/text/428914.html

Определение Освященного Архиерейского Собора Русской Православной Церкви «О вопросах внутренней жизни и внешней деятельности Русской Православной Церкви»

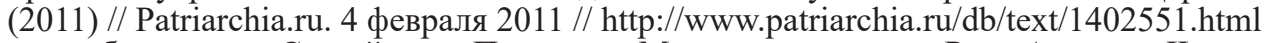

Открытое обращение к Святейшему Патриарху Московскому и всея Руси Алексию II, членам Священного Синода, архипастырям, пастырям, монашествующим, мирянам Русской Православной Церкви и всем гражданам России (2004) // Константин Гордеев // http://www.kongord.ru/Index/A tma 04/opendec1080304.html

Панченко А.А. (2015) Компьютер по имени Зверь: эсхатология и конспирология в современных религиозных культурах // Антропологический форум. № 27. С. 122-141.

Парламентарии не поняли смысл закона о биометрической идентификации № 482-ФЗ! Требуем отмены закона! (2018) // РИА «Катюша». 26 января 2018 // http://katyusha.org/view?id=9290 
Позиция Церкви в связи с развитием технологий учета и обработки персональных данных (2013) // Patriarchia.ru. 4 февраля 2013 // http://www.patriarchia.ru/db/text/2775107.html

Послание Священного Синода Русской Православной Церкви епископату, клиру, монашествующим и мирянам в связи с нашедшим в этом году вредоносным поветрием (2020) // Patriarchia.ru. 25 августа 2020 // http://www.patriarchia.ru/db/text/5682118.html

Предстоятель Русской Церкви встретился в Сарове с российскими учеными-ядерщиками (2019) // Patriarchia.ru. 31 июля 2019 // http://www.patriarchia.ru/db/text/5480165.html

Принудительная оцифровка личности или свобода человека (2019) // Канал «40тв». 20 апреля $2019 / /$ https://www.youtube.com/watch?v=1oUpd3z3tHs\&

Проект «Цифровая экономика РФ» несет угрозу безопасности страны (2017) // Русская народная линия. 10 июля 2017 // https://ruskline.ru/news_rl/2017/07/10/proekt_cifrovaya ekonomika_rf_nesyot_ugrozu_bezopasnosti_strany_i_ne_dolzhen_stat_ideologiej_novoj_ raschelovechēnnoj_rossii/

Романов С. (2020) Кто готовит рабство в России // Rustik1961. 9 июня 2020 // https://youtu.be/CQffdb3nMdo

Российский священник проклял сторонников закрытия храмов из-за коронавируса (2020) // Lenta.ru. 26 апреля 2020 // https://lenta.ru/news/2020/04/26/protivhramov/

Скобцова М. (2012) Типы религиозной жизни // Православие и мир. 31 марта 2012 // https://www.pravmir.ru/tipy-religioznoj-zhizni/

Смирнов М.Ю. (2019) Цифровизация как «обнуление религии» // Вестник Ленинградского государственного университета им. А.С. Пушкина. № 3. С. 137-146.

Сошенко А. (2020) От коронавируса - к единому электронному концлагерю // Русская народная линия. 16 марта 2020 // https://ruskline.ru/news_rl/2020/03/16/ot_koronavirusa_k_edinomu_elektronnomu_konclageryu

Тотальный контроль делает общество более управляемым (2013) // Русская народная линия. 25 июля 2013 // https://ruskline.ru/news_rl/2013/07/25/ totalnyj_kontrol_delaet_obwestvo_bolee_upravlyaemym/

Требуем отклонить законопроект о- «реестре населения» и защитить персональные данные граждан в Конституции! (2020) // РИА «Катюша». 19 февраля 2020 // http://katyusha.org/view?id=13736

Филимонов В.П. (2019) Государственный переворот? // Русская народная линия. 21 ноября $2019 / / \mathrm{https}: / /$ ruskline.ru/news_rl/2019/11/21/gosudarstvennyi_perevorot

Филимонов В.П. (1) (2020) Валерий Филимонов на круглом столе по цифровизации // РИА «Катюша». 20 марта 2020 // https:/www.youtube.com/watch?v=uI-JwdWMsvg

Филимонов В.П. (2) (2020) Коронавирус пройдет, рано или поздно, а вот тотальная слежка останется // Русская народная линия. 1 апреля 2020 // https://ruskline.ru/news_rl/2020/04/01/koronavirus_proidet_rano_ili_pozdno_a_vot_ totalnaya_slezhka_ostanetsya

Центр Пью: дйстанционная школа - это катастрофа образования (2020) // РИА «Катюша». 29 апреля $2020 / / \mathrm{http}: / /$ katyusha.org/view?id=14205

Цифровая продажа Родины (2017) // РИА «Катюша». 28 июля 2017 // http://katyusha.org/view?id=7240

Четверикова О. (2020) Тайна частной жизни отменяется новым законом! // Otpustisebya na svobodu. 28 июля 2020 // https://youtu.be/RBsvoKLc1D4

Шнирельман В. (2017) Колено Даново: эсхатология и антисемитизм в современной России. М.: Издательство Библейско-богословского института.

Barkun M. (2003) A Culture of Conspiracy. Apocaliptic Visions in Contemporary America, Berkeley, Los Angeles: University of California Press.

Boyer P. (1992) When Time Shall Be No More: Prophecy Belief in Modern American Culture, Cambridge, MA: Belknap Press.

Casanova J. (1992) Private and Public Religions // Social Research, vol. 59, no 1, pp. 17-57.

Heclo H., McClay W.M. (2003) Religion Returns to the Public Square: Faith and Policy in America, Washington: Woodrow Wilson Center Press; Baltimore, London: The John Hopkins University Press.

Lawrence B. (1989) Defenders of God: The Fundamentalist Revolt Against the Modern Age, L., N.Y.: I.B. Turis \& Co. 
Lyon D. (1994) The Electronic Eye: The Rise of Surveillance Society, Minneapolis: University of Minnesota Press.

Østbø J. (2017) Securitizing "Spiritual-moral Calues" in Russa // Post-Soviet Affairs, vol. 33, no 3, pp. 200-216.

Richards N. (2013) The Dangers of Surveillance // Harvard Law Review, pp. 1934-1965.

Riesebrodt M. (1998) Pious Passion. The Emergence of Modern Fundamentalism in the United States and Iran, L.A.-L.: Berkeley.

Verkhovsky A. (2002) The Role of the Russian Orthodox Church in Nationalist, Xenophobic and Anti-Western Tendencies in Russia Today: Not Nationalism, but Fundamentalism // Religion, State and Society, no 30, pp. 333-345.

Wynn M. (2009) Faith and Place: An Essay in Embodied Religious Epistemology, Oxford University Press.

Zabaev I., Mikhailova Y., Oreshina D. (2018) Neither Public nor Private Religion: The Russian Orthodox Church in the Public Sphere of Contemporary Russia // Journal of Contemporary Religion, vol. 33, no 1, pp. 17-38.

\title{
In the Beginning Was the Word; Will a Number Be in the End? Orthodoxy and Anti-digital Protest in Russia: From the 1990s to the Coronavirus
}

\author{
B. KNORRE*, A. MURASHOVA**
}

\begin{abstract}
*Boris Knorre - PhD in Philosophy, Associate Professor, Senior Researcher, National Research University Higher School of Economics. Address: 20, Myasnitskaya St., Moscow, 101000, Russian Federation. E-mail: bknorre@hse.ru

**Anna Murashova - Research Assistant, National Research University Higher School of Economics. Address: 20, Myasnitskaya St., Moscow, 101000, Russian Federation. E-mail: murashova.hse@gmail.com

Citation: Knorre B., Murashova A. (2021) In the Beginning Was the Word; Will a Number $\mathrm{Be}$ in the End? Orthodoxy and Anti-digital Protest in Russia: From the 1990s to the Coronavirus. Mir Rossii, vol. 30, no 2, pp. 146-166 (in Russian). DOI: 10.17323/1811-038X-2021-30-2-146-166
\end{abstract}

\begin{abstract}
This article focuses on the development of anti-digital protests among Orthodox fundamentalists and conservatives in Russia. The goal is to reveal the main trends in Russian Orthodoxy concerning the opposition to the introduction of electronic means of personal data control, and the ideas on which the respective arguments are based. We consider the period from the late 1990s to the summer of 2020, starting with the first protests against the use of barcodes and taxpayer identification numbers (VATIN value added tax identification number) and ending with the reaction of Orthodox movements to the digitization initiatives of the state authorities during the COVID-19
\end{abstract}


pandemic. We show that although the anti-digital protest is mainly associated with fundamentalist and the most conservative movements in Russian Orthodoxy, which are largely based on archaic or "traditional" values, the representatives of such groups in recent years have increasingly turned to the values of freedom and even to the human rights discourse that is widespread in the West. We also discover two clusters in modern Russian Orthodoxy: one focused on the physical mediation of interaction with the transcendent, and the other on the intellectual and ethical understanding of religion. Representatives of the former cluster are not simply much less worried about the introduction of digital technologies; they even welcome the use of online technologies in religious practice.

Keywords: Orthodoxy, digitalization, Russian Orthodox Church, conservatism, fundamentalism, personal data protection, COVID-19

\section{References}

Barkun M. (2003) A Culture of Conspiracy. Apocaliptic Visions in Contemporary America, Berkeley, Los Angeles: University of California Press.

Bogolyubov I.D. (2000) Ne speshite kayat'sya za vsekh [Do not Rush to Repent for Everyone]. Pravoslavie.ru. Available at: https://narod.pravoslavie.ru/shengen/kuraev_inn.htm, accessed 20.02.2021.

Boyer P. (1992) When Time Shall Be No More: Prophecy Belief in Modern American Culture, Cambridge, MA: Belknap Press.

Casanova J. (1992) Private and Public Religions. Social Research, vol. 59, no 1, pp. 17-57.

Chetverikova O. (2020) Tajna chastnoj zhizni otmenyayetsya novym zakonom! [Privacy Is Abolished with a New Law!]. "Otpustisebya na svobodu”, July 28, 2020. Available at: https://youtu.be/RBsvoKLc1D4, accessed 20.02.2021.

Do samoy suti: Biometricheskoye rabstvo [To the Essence. Biometric Slavery] (2018). Channel "SPAS", December 5, 2020. Available at: https://www.youtube.com/watch?v=O5mmr8_rwg4, accessed 20.02.2021.

Do samoy suti: Elektronnyj kontslager' [To the Essence. Electronic Concentration Camp] (2019). Channel "SPAS", July 24, 2019. Available at: https://www.youtube.com/watch?v=I8HJN16iGCw, accessed 20.02.2021.

Filimonov V. (2019) Gosudarstvennyy perevorot? [A Coup d'État?]. Russkaya narodnaya liniya, November 21, 2019. Available at: https://ruskline.ru/news_rl/2019/11/21/gosudarstvennyi_ perevorot, accessed 20.02.2021.

Filimonov V. (1) (2020) Valeriy Filimonov na kruglom stole po tsifrovizatsii [Valery Filimonov at the Round Table on Digitalization]. RIA "Katyusha", March 20, 2020. Available at: https://www.youtube.com/watch?v=uI-JwdWMsvg, accessed 20.02.2021.

Filimonov V. (2) (2020) Koronavirus proydet, rano ili pozdno, a vot total'naya slezhka ostanetsya [The Coronavirus Will Pass, Sooner or Later, but Total Surveillance Will Remain]. Russkaya narodnaya liniya, April 1, 2020. Available at: https://ruskline.ru/news_rl/2020/04/01/koronavirus_proidet_rano_ili_pozdno_a_vot_ totalnaya_slezhka_ostanetsya, accessed 20.02.2021.

Gavryushin N.K. [A.M.] (1983) Voskreshenie chaemoe ili voskhishchaemoe? [Resurrection: Desired or Admired?]. Bogoslovskie trudy, no 24, pp. 242-259.

Heclo H., McClay W.M. (2003) Religion Returns to the Public Square: Faith and Policy in America, Washington: Woodrow Wilson Center Press; Baltimore, London: The John Hopkins University Press. 
Itogovyj dokument VII Plenuma Sinodal'noj Bogoslovskoj komissii Russkoy Pravoslavnoy Tserkvi, posvyashchennoy voprosu ob INN [The Final Document of the VII Plenum of the Synodal Theological Commission of the Russian Orthodox Church on the Issue of VATIN] (2001). Azbuka very, March 4, 2001. Available at: https://azbyka.ru/otechnik/dokumenty/ itogovyj-dokument-7-plenuma-sinodalnoj-bogoslovskoj-komissii-russkoj-pravoslavnojtserkvi-posvjashhennoj-voprosu-ob-inn/, accessed 20.02.2021.

Ivatkina M. (2019) «Zapasites' valer'yankoy»: eksperty raskritikovali zakonoproyekt «O tsifrovom profile» ["Stock up on Valerian": Experts Criticized the Draft Law "On the Digital Profile"]. Tsargrad-TV, November 14, 2019. Available at: https://tsargrad.tv/articles/zapasites-valerjankoj-jeksperty-raskritikovali-zakonoproekt-ocifrovom-profile 225857, accessed 20.02.2021.

Katasonov V.Yu. (2019) V nachale bylo Slovo, a v kontse budet tsifra. Stat'i i ocherki [In the Beginning Was the Word, and at the End There Will Be a Number. Articles and Essays], Moscow: Kislorod.

Kolesnik M. (2020) Post. VKontakte, April 21, 2020. Available at: https://vk.com/wall211228203 4100, accessed 20.02.2021.

Korchagin L. (2020) Post. ${ }^{-}$VKontakte, April 18, 2020. Available at: https://vk.com/wall434012891_2381, accessed 20.02.2021.

Lampsi A. (2001) INN v pravoslavnykh SMI [VATIN in the Orthodox Media]. NG-religii, February 28, 2001. Available at: https://www.ng.ru/ng_religii/2001-02-28/5_analysis.html, accessed 20.02.2021.

Lawrence B. (1989) Defenders of God: The Fundamentalist Revolt Against the Modern Age, L., N.Y.: I.B. Turis \& Co.

Lyon D. (1994) The Electronic Eye: The Rise of Surveillance Society, Minneapolis: University of Minnesota Press.

Medvedeva I., Shishova T. (2020) Popytka nravstvennogo perevorota [An Attempt at a Moral Overturn]. RIA “Katusha”, June 24, 2020. Available at: http://katyusha.org/view?id=14604, accessed 20.02.2021.

Mitrofanova A. (2004) Politizatsiya «pravoslavnogo mira» [The Politicization of "the Orthodox World"], Moscow: Nauka.

Narodnye protesty zastavili Dumu otlozhit' rassmotreniye zakonoproyekta o registre naseleniya na nedelyu i snyat's povestki biometriyu [People's Protests Forced the Duma to Postpone the Consideration of the Bill on the Population Register for a Week and Remove Biometrics from the Agenda] (2020). Personal Data Protection Committee, May 14, 2020. Available at: http://cifroskeptik.net/2020/05/14/narodnye-protesty-zastavili-dumu-otl/, accessed 20.02.2021.

Novikova-Stroganova A. (2019) Elektronno-torgovaya kabala [E-commerce Bondage]. Radonezh, December 18, 2014. Available at: https://radonezh.ru/analytics/elektronnotorgovaya-kabala-122420.html, accessed 20.02.2021.

Onlain-miting «Chelovek ne nomer» [Online Meeting “A Human Is not a Number"] (2020). "Ivan-Chay", May 6, 2020. Available at: https://www.youtube.com/watch?v=1g4E3Xltdgc, accessed 20.02.2021.

Opredeleniye Osvyashchennogo Arkhiyereyskogo Sobora Russkoy Pravoslavnoy Tserkvi 24-29 iyunya 2008 goda "O voprosakh vnutrenney zhizni i vneshney deyatel'nosti Russkoy Pravoslavnoy Tserkvi» [Resolution of the Russian Orthodox Church Consecrated Council of Bishops on June 24-29, 2008 "On Issues of Internal Life and External Activity of the Russian Orthodox Church"] (2008). Patriarchia.ru, June 27, 2008. Available at: http://www.patriarchia.ru/db/text/428914.html, accessed 20.02.2021.

Opredeleniye Osvyashchennogo Arkhiyereyskogo Sobora Russkoy Pravoslavnoy Tserkvi «O voprosakh vnutrenney zhizni i vneshney deyatel'nosti Russkoy Pravoslavnoy Tserkvi» [Resolution of Russian Orthodox Church Consecrated Council of Bishops "On the Issues of Internal Life and External Activity of the Russian Orthodox Church"] (2011). Patriarchia.ru, February 4, 2011. Available at: http://www.patriarchia.ru/db/text/1402551.html, accessed 20.02.2021.

Østbø J. (2017) Securitizing "Spiritual-moral Calues" in Russa. Post-Soviet Affairs, vol. 33, no 3, pp. 200-216. 
Otkrytoye obrashcheniye k Svyateyshemu Patriarkhu Moskovskomu i vseya Rusi Aleksiyu II, chlenam Svyashchennogo Sinoda, arkhipastyryam, pastyryam, monashestvuyushchim, miryanam Russkoy Pravoslavnoy Tserkvi i vsem grazhdanam Rossii [Open Appeal to His Holiness Patriarch of Moscow and All Russia Alexy II, Members of the Holy Synod, Archpastors, Pastors, Monastics, Laity of the Russian Orthodox Church and All Citizens of Russia] (2004). Konstantin Gordeev. Available at: http://www.kongord.ru/Index/A tma 04/opendec1080304.html, accessed 20.02.2021.

Panchenko A. (2015) Komp'yuter po imeni Žver': eskhatologiya i konspirologiya v sovremennykh religioznykh kul'turakh [A Computer Called the Beast: Eschatology and Conspiracy in Contemporary Religious Cultures]. Antropologicheskiy Forum, no 27, pp. 122-141.

Parlamentarii ne ponyali smysla zakona o biometricheskoy baze № 482-FZ! Trebuyem otmeny zakona! [Parliamentarians Did not Understand the Meaning of the Law on Biometric Identification No. 482-FZ! We Demand the Repeal of the Law!] (2018). RIA "Katyusha", January 26, 2018. Available at: http://katyusha.org/view?id=9290, accessed 20.02.2021.

Poslaniye Svyashchennogo Sinoda Russkoy Pravoslavnoy Tserkvi yepiskopatu, kliru, monashestvuyushchim i miryanam $\mathrm{v}$ svyazi $\mathrm{s}$ nashedshim $\mathrm{v}$ etom godu vredonosnym povetriyem [Epistle of the Holy Synod of the Russian Orthodox Church to the Episcopate, Clergy, Monastics and Laity in Connection with a Harmful Epidemic This Year] (2020). Patriarchia.ru, August 25, 2020. Available at: http://www.patriarchia.ru/db/text/5682118.html, accessed 20.02.2021.

Pozitsiya Tserkvi v svyazi s razvitiyem tekhnologiy ucheta i obrabotki personal'nykh dannykh [The Position of the Church on the Development of Technologies for Accounting and Processing of Personal Data] (2013). Patriarchia.ru, February 4, 2013. Available at: http://www.patriarchia.ru/db/text/2775107.html, accessed 20.02.2021.

Predstoyatel' Russkoy Tserkvi vstretilsya v Sarove s rossiyskimi uchenymiyadershchikami [The Primate of the Russian Church Met in Sarov with Russian Nuclear Scientists] (2019). Patriarchia.ru, July 31, 2019. Available at: http://www.patriarchia.ru/db/text/5480165.html, accessed 20.02.2021.

Prinuditel'naya otsifrovka lichnosti ili svoboda cheloveka [Forced Digitization of Personality or Human Freedom] (2019). Channel "40tv", April 20, 2019. Available at: https://www.youtube.com/watch? $\mathrm{v}=1 \mathrm{oUpd} 3 \mathrm{z} 3 \mathrm{tHs} \&$, accessed 20.02.2021.

Proyekt «Tsifrovaya ekonomika RF» nesyot ugrozu bezopasnosti strany [The Project "Digital Economy of the Russian Federation" Poses a Threat to the Country's Security] (2017). Russkaya narodnaya liniya, July 10, 2017. Available at: https://ruskline.ru/news rl/2017/07/10/proekt_cifrovaya_ekonomika_rf_nesyot_ugrozu_bezopasnosti_strany_i_ ne_dolzhen_stat_ideōogiej_novoj_raschelovechēennoj_rossii/, accessed 20.02.20 21 .

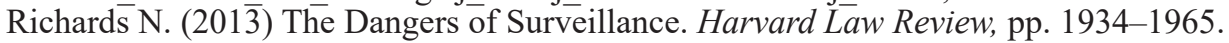

Riesebrodt M. (1998) Pious Passion. The Emergence of Modern Fundamentalism in the United States and Iran, L.A.-L.: Berkeley.

Romanov S. (2020) Kto gotovit rabstvo v Rossii [Who Is Preparing Slavery in Russia]. Rustik1961, June 9, 2020. Available at: https://youtu.be/CQffdb3nMdo, accessed 20.02.2021.

Rossijskij svyashchennik proklyal storonnikov zakrytiya khramov iz-za koronavirusa [Russian Priest Curses Supporters of Closing Churches Due to Coronavirus] (2020). Lenta.ru, April 26, 2020. Available at: https://lenta.ru/news/2020/04/26/protivhramov/, accessed 20.02.2021.

Shnirel'man V. (2017) Koleno Danovo: eskhatologiya $i$ antisemitizm v sovremennoy Rossii [The Tribe of Danovo: Eschatology and Anti-Semitism in Modern Russia], Moscow: Izdatel'stvo Bibleysko-bogoslovskogo instituta.

Skobtsova M. (2012) Tipy religioznoy zhizni [Types of Religious Life]. Pravoslavie $i$ mir, March 31, 2012. Available at: https://www.pravmir.ru/tipy-religioznoj-zhizni/, accessed 20.02.2021.

Smirnov M.Yu. (2019) Tsifrovizatsiya kak «obnuleniye religii» [Digitalization as "Zeroing of Religion"]. Bulletin of the Leningrad State University named after A. S. Pushkin, no 3, pp. $137-146$.

Soshenko A. (2020) Ot koronavirusa - k yedinomu elektronnomu kontslageryu [From Coronavirus to a Universal Electronic Concentration Camp]. Russkaya narodnaya liniya, March 16, 2020. 
Available at: https://ruskline.ru/news_rl/2020/03/16/ot_koronavirusa_k_edinomu_ elektronnomu konclageryu, accessed 20.02.2021.

Total'nyy kontrol' delayet obshchestvo boleye upravlyayemym [Total Control Makes Society More Manageable] (2013). Russkaya narodnaya liniya, July 25, 2013. Available at: https://ruskline.ru/news rl/2013/07/25/totalnyj_kontrol_delaet_obwestvo_bolee upravlyaemym/, accessed 20.02 .2021 .

Trebuyem otklonit' zakonoproyekt o «reyestre naseleniya» i zashchitit' personal'nyye dannyye grazhdan v Konstitutsii! [We Demand to Reject the Bill on the "Population Register" and Protect the Personal Data of Citizens in the Constitution!] (2020). RIA "Katyusha", February 19, 2020. Available at: http://katyusha.org/view?id=13736, accessed 20.02.2021.

Tsentr P'yu: distantsionnaya shkola - eto katastrofa obrazovaniya [Pew Center: Distance Education Is a Disaster in Education] (2020). RIA "Katyusha", April 29, 2020. Available at: http://katyusha.org/view?id=14205, accessed 20.02.2021.

Tsifrovaya prodazha Rodiny [Digital Sale of the Motherland] (2017). RIA "Katyusha", July 28, 2017. Available at: http://katyusha.org/view?id=7240, accessed 20.02.2021.

Verkhovsky A. (2002) The Role of the Russian Orthodox Church in Nationalist, Xenophobic and Anti-Western Tendencies in Russia Today: Not Nationalism, but Fundamentalism. Religion, State and Society, no 30, pp. 333-345.

Verkhosky A.M. (2003) Politicheskoe pravoslavie: Russkie pravoslavnye natsionalisty $i$ fundamentalisty, 1995-2001 [Political Orthodoxy: Russian Orthodox Nationalists and Fundamentalists, 1995-2001], Moscow: Center "Sova".

Wynn M. (2009) Faith and Place: An Essay in Embodied Religious Epistemology, Oxford University Press.

Zabaev I., Mikhailova Y., Oreshina D. (2018) Neither Public nor Private Religion: The Russian Orthodox Church in the Public Sphere of Contemporary Russia. Journal of Contemporary Religion, vol. 33, no 1, pp. 17-38.

Zayavleniye Svyashchennogo Sinoda [Statement of the Holy Synod] (2000). Patriarchia.ru, March 7, 2000. Available at: http://www.patriarchia.ru/db/text/4898206.html, accessed 20.02.2021. 